\title{
Effects of spent mushroom compost application on the physicochemical properties of a degraded soil
}

\author{
İlknur Gümüş and Cevdet Şeker \\ Department of Soil Science and Plant Nutrition, Faculty of Agriculture, University of Selçuk, 42031 Konya, Turkey \\ Correspondence to: İlknur Gümüş (ersoy@ selcuk.edu.tr)
}

Received: 18 August 2016 - Discussion started: 30 September 2016

Revised: 27 July 2017 - Accepted: 24 September 2017 - Published: 6 November 2017

\begin{abstract}
Under field and laboratory conditions, the application of organic amendments has generally shown an improvement in soil physicochemical properties. Here, spent mushroom compost (SMC) is proposed as a suitable organic amendment for soil structure restoration. Our study assessed the impact of SMC on the physicochemical properties of a weak-structured and physically degraded soil. The approach involved the establishment of a pot experiment with SMC applications into soil (control, 0.5, 1, 2, 4 and $8 \%$ ). Soils were incubated at field capacity ( $-33 \mathrm{kPa}$ ) for 21,42 , and 62 days under laboratory conditions. SMC applications into the soil significantly increased the aggregate stability (AS) and decreased the modulus of rupture. The application of SMC at rates of $1,2,4$, and $8 \%$ significantly increased the total nitrogen and soil organic carbon contents of the degraded soil at all incubation periods $(p<0.05)$. The results obtained in this study indicate that the application of SMC can improve soil physicochemical properties, which may benefit farmers, land managers, and mushroom growers.
\end{abstract}

\section{Introduction}

Soil quality is defined as the capacity of the soil to function within natural or managed ecosystems and land use boundaries, sustain biological productivity (Calleja-Cervantes et al., 2015; Dai et al., 2015), promote air quality and water environments, and maintain plant, animal, and human health (Doran et al., 1997; Karlen et al., 1997). Physical and chemical properties are the main indicators used to assess soil quality (Bone et al., 2014; Paz-Ferreiro and Fu, 2013; Pulido Moncada et al., 2015). Soil quality can be threatened by the increase in human activities such as urbanization and in- tensive agricultural activities (Paz-Ferreiro and Fu, 2013). Moreover, it is an important aspect closely related to soil degradation, which decreases land potential productivity (Yu and Jia, 2014). The climatic patterns of dry lands can be divided into three types: arid, semiarid, and subhumid dry areas from various factors, including climatic variations and human activities (Yu and Jia, 2014). Soil degradation is a particularly serious problem in Mediterranean areas where the effects of anthropogenic activities are compounded by the problems caused by prolonged periods of drought and intense and irregular rainfall (Hueso-González et al., 2014; Rodrigo-Comino et al., 2016, 2017). Vegetation degradation and land use change are among the soil degradation factors that cause soil carbon and nitrogen losses (García-Díaz et al., 2016, 2017; Moreno et al., 2016; Peng et al., 2015). Deterioration in soil structure is considered a form of soil degradation (Chan et al., 2003) and is frequent with regards to land use and soil crop management practices.

Soil physical degradation in agricultural areas occurs mostly as a consequence of a decrease in soil organic matter caused by excessive soil cultivation (Grandy et al., 2002). Intensive soil cultivation can lead to a decrease in soil organic matter content, resulting in a decrease in aggregate stability and a greater risk of soil erosion (Annabi et al., 2011). Şeker and Karakaplan (1999) reported that the loss of organic matter is generally associated with a decrease in soil porosity and wet aggregate stability. Soil water movement and retention capacity, crusting, root penetration, crop yield, erosion, and nutrient cycling are influenced by soil structure (Bal et al., 2012; Bronick and Lal, 2005; Şeker, 2003).

Organic materials are important soil additives that help to improve soil physical, chemical, and biological properties and the overall soil fertility (Wu et al., 2014). In addition 
to productive yields, these organic materials have been beneficial for soil chemical and physical fertility and stability (Mukherjee et al., 2014). Therefore, organic materials can be applied to soils to increase their organic matter contents and restore their physical properties, including soil aggregate stability (Annabi et al., 2011; Özdemir et al., 2007). In semiarid regions such as Turkey, low organic matter contents can significantly affect soil productivity (Gümüs and Şeker, 2015).

Mushroom cultivation has recently become very popular in Turkey and is a promising new industry with many new businesses developing every year. Mushroom production in Turkey is separated into two components: compost production and mushroom cultivation (Erler and Polat, 2008; Tui k, 2015). Compost application to agricultural soil has been widely practiced as one approach to improve crop productivity and soil fertility (Jaiarree et al., 2014). Spent mushroom compost is either spread on land or dumped in landfills, and only a small proportion is used as a soil amendment or as potting material (Ko et al., 2005; Zhang and Sun, 2014). Thus, this type of compost can be used in organic farming to improve soil water infiltration, water holding capacity, permeability, and aeration (Uzun, 2004). Composts provide a stabilized form of organic matter that improves the physical properties of soils by increasing both nutrient and water holding capacity, total pore space, aggregate stability, erosion resistance, and temperature insulation (Shiralipour et al., 1992). SMC possesses many beneficial characteristics including a relatively low bulk density, a low level of heavy metals, and an absence of plant pathogens and weed seeds (Curtin and Mullen, 2007; Zhang and Sun, 2014).

Therefore, the main goal of this study was to assess the effects of SMC application to weak-structured and physically degraded soil in semiarid Turkey with a specific emphasis on aggregate stability, the modulus of rupture, electrical conductivity (EC), nitrogen, and organic carbon.

\section{Materials and methods}

\subsection{Study area}

Soil for our study was collected from an experimental plot at the experiment station of the Agricultural Faculty at Selçuk University (0-20 cm top soil layer) near the village of Konya Saricalar $(30 \mathrm{~km}$ north of the city of Konya) located in Central Anatolia, Turkey (latitude $38^{\circ} 05^{\prime} 56^{\prime \prime} \mathrm{N}$, longitude $32^{\circ} 36^{\prime} 29^{\prime \prime} \mathrm{E} ; 1009 \mathrm{~m}$ a.s.l.). The experiment station covers an area of 1200 ha and the climate type is semiarid with annual precipitation of $379.38 \mathrm{~mm}$, an annual mean temperature of $11.5^{\circ} \mathrm{C}$, and annual mean evaporation of $1226.4 \mathrm{~mm}$ (MGM, 2015). Soil moisture and temperature regimes are xeric and mesic, respectively, according to the available data (Soil Survey Staff, 2014). Soil is classified as Entisol (Soil Survey Staff, 2014). The area has a typically rain-fed attribute with cultivation practices and various crops such as grains, sugar

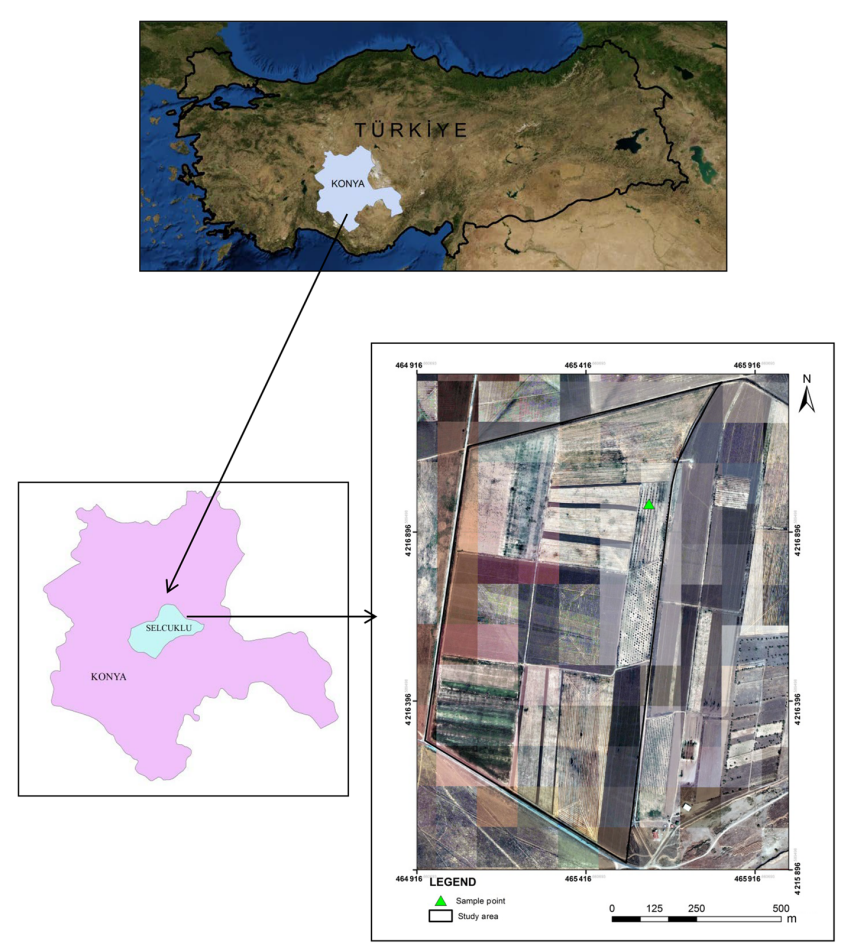

Figure 1. Geographical location of the experiment station of the Agricultural Faculty at Selçuk University.

beet, and corn with fruit trees of various ages. Soil used in this study has shown insufficient seedling emergency, low aggregate stability, soil crust formation problem, and low organic matter content (Bal et al., 2012). The SMC used in this study was obtained from a private company dedicated to mass mushroom production located in Konya, Turkey.

\subsection{Methods}

The experiment was carried out in a completely randomized plot design with three replications and conducted under laboratory conditions $\left(22^{\circ} \mathrm{C} \pm 3\right)$ as a pot experiment. Surface soil samples $(0-20 \mathrm{~cm})$ were air-dried, ground, passed through a $2 \mathrm{~mm}$ sieve, and mixed homogeneously. First, soil samples (each weighing $2 \mathrm{~kg}$ ) were placed in pots. Six levels of SMC were mixed into the soil and incubated: 0 (as a control), $0.5,1,2,4$, and $8 \%$ by weight basis. During the incubation period, the soil moisture level in the pots was maintained at field capacity. After various incubation periods (21, 42, and 62 days), soil samples were collected from each pot and mixed to ensure homogeneity in the soil subsamples. Soils were then subsampled $(250 \mathrm{~g})$ for analyses.

Particle size distribution was determined by using the hydrometer method (Gee et al., 1986). The soil water contents at field capacity and wilting point were determined with a pressure plate device (Cassel and Nielsen, 1986) at -33 and $-1500 \mathrm{kPa}$, respectively. Soil $\mathrm{pH}$ and EC values were determined by using a glass-calomel electrode in a $1: 2.5$ mix- 


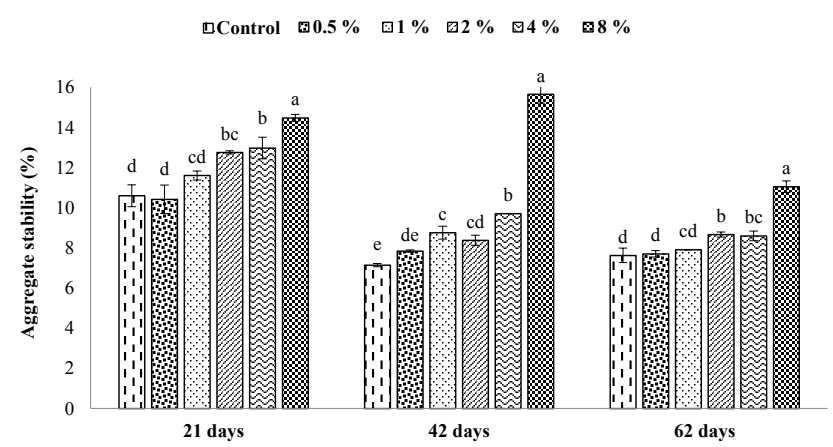

Figure 2. Effects of different rates of SMC application on aggregate stability (mean $\pm \mathrm{SD}<0.05$ ). Means followed by the same letter are not statistically different as determined by a least significant difference test.

ture $(w / v)$ of soil and water; SMC $\mathrm{pH}$ and EC samples were mixed with water 1: 5 (Rhoades et al., 1996; Thomas, 1996). Soil organic carbon was determined for samples ground to pass through a $0.5 \mathrm{~mm}$ sieve by the use of TruSpec CN Carbon/Nitrogen Determinator (Leco Corporation, 2003). The modulus of rupture was determined at $0.5 \mathrm{kPa}$ of sensitivity with the procedure of Richards (1953) using briquettes prepared in moulds made from mild steel with a rectangular cross section and with interior dimensions of $7 \times 3.5 \times 1 \mathrm{~cm}$. The briquettes were prepared by using sieved subsoil samples $(<2 \mathrm{~mm})$ taken from every pot, which were then placed in a soaking tank of distilled water filled to the upper surface of the mould. They were allowed to stand for $1 \mathrm{~h}$, and then dried at $50^{\circ} \mathrm{C}$. The briquettes were broken by the downward motion of a bar at a triangular cross section, with the force being applied by water addition to a vessel. The modulus of rupture was calculated as follows:

MR : $3 F L / 2 b d^{2} 10000$,

where MR is the modulus of rupture $(\mathrm{kPa}), F$ is the breaking force in grams of water $\times 980, L$ is the distance between the lower supports in $\mathrm{cm}, b$ is the width of the briquette in $\mathrm{cm}$, and $d$ is the thickness of the briquette in $\mathrm{cm}$ (Reeve, 1965; Richards, 1953). Aggregate stability was determined by immersing the sieves containing the aggregate samples (1-2 mm size) in distilled water at up and down oscillations on screens through $55 \mathrm{~mm}$ at 30 strokes $\mathrm{min}^{-1}$ for 5 min (Kemper and Rosenau, 1986).

Data collected were subjected to a one-way analysis of variance (ANOVA) test to assess differences in the studied parameters among the treatments: aggregate stability, modulus of rupture, EC, organic C, and total N. Means were compared at $p<0.05$ using the Fisher's LSD significant difference test (Minitab, 1991, State College, PA, USA).

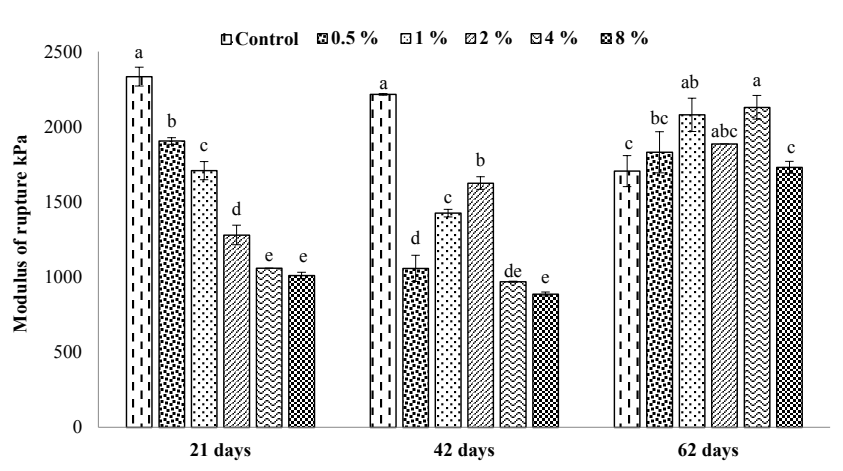

Figure 3. Effects of different rates of SMC application on soil modulus of rupture (mean $\pm \mathrm{SD}<0.05$ ). Means followed by the same letter are not statistically different as determined by a least significant difference test.

\section{Results and discussion}

Some of the physical and chemical properties of soil and SMC are shown in Tables 1 and 2. The soil was characterized as having a clay texture, an alkaline soil $\mathrm{pH}$ (7.96), and organic $\mathrm{C}$ and $\mathrm{CaCO}_{3}$ contents of 1.35 and $11.58 \%$, respectively.

\subsection{Aggregate stability (AS)}

The effects of SMC application on aggregate stability are shown in Fig. 2. Aggregate stability decreased after 42 and 62 days of incubation in all SMC rates when compared to a 21-day incubation period. The effects of SMC application on soil aggregate stability values were significant. These results may be explained by the decomposition of soil organic matter (Carrizo et al., 2015; Şeker, 2003). Aggregate stability and soil organic matter are two parameters and indicators for soil quality or productivity. The recovery in aggregate stability of such physically degraded soils is important, as those studied were expected to follow the incorporation of any cementing agent, such as SMC (Curtin and Mullen, 2007). Soil organic matter has been suggested to be the most important factor in the determination of soil aggregate stability because of the significant positive relationships between these two parameters (Aksakal et al., 2015; Candemir and Gülser, 2010; Cerdà, 1998). Thus, the application of organic materials has been proposed to improve the physical properties of degraded soils (Turgut and Kose, 2016). Similar studies have reported an increase in the soil organic carbon concentration after organic matter application and thus a higher formation of stable aggregates (Díaz et al., 1994; Cerdà, 1998; Aggelides and Londra, 2000; Celik et al., 2004; Arthur et al., 2011; Ferreras et al., 2006; Gümüs and Şeker, 2015; Murphy, 2001). 
Table 1. Properties of the soil used in the experiment (mean \pm SD).

\begin{tabular}{lrlr}
\hline Soil properties & Values & Soil properties & Values \\
\hline Sand $(2-0.05 \mathrm{~mm} ; \%)$ & $7 \pm 0.48$ & Field capacity (\%) & $35.6 \pm 0.87$ \\
Silt $(0.05-0.002 \mathrm{~mm} ; \%)$ & $34 \pm 0.56$ & Wilting point (\%) & $16.2 \pm 0.96$ \\
Clay $(<0.002 \mathrm{~mm} ; \%)$ & $59 \pm 0.51$ & Aggregate stability (\%) & $10.83 \pm 1.56$ \\
Textural class & $\mathrm{C}$ & Bulk density $\left(\mathrm{g} \mathrm{cm}^{-3}\right)$ & $1.09 \pm 0.02$ \\
$\mathrm{pH}\left(\mathrm{H}_{2} \mathrm{O}, 1: 2.5\right)$ & $7.96 \pm 0.12$ & & \\
$\mathrm{EC}\left(\mathrm{H}_{2} \mathrm{O}, 1: 2.5\right) \mu \mathrm{S} \mathrm{cm}^{-1}$ & $479 \pm 1.58$ & & \\
$\mathrm{C}(\%)$ & $1.35 \pm 0.03$ & & \\
Total $\mathrm{N}(\%)$ & $0.09 \pm 0.00$ & & \\
Carbonates $(\%)$ & $11.58 \pm 0.69$ & & \\
\hline
\end{tabular}

Table 2. Properties of the SMC.

\begin{tabular}{ll}
\hline Properties & SMC \\
\hline $\mathrm{pH}\left(\mathrm{H}_{2} \mathrm{O}, 1: 5\right)$ & 7.36 \\
$\mathrm{EC}\left(\mathrm{H}_{2} \mathrm{O}, 1: 5\right) \mu \mathrm{S} \mathrm{cm}^{-1}$ & 5390 \\
$\mathrm{C}(\%)$ & 38.80 \\
$\mathrm{~N}(\%)$ & 2.61 \\
$\mathrm{C} / \mathrm{N}$ & 14.88 \\
Organic matter $(\%)$ & 66.89 \\
\hline
\end{tabular}

\subsection{Soil modulus of rupture}

The effects of SMC application on the soil modulus of rupture are shown in Fig. 3. All the SMC applications resulted in a significantly lower soil modulus of rupture after the 21 st and 42nd days compared to the 62-day incubation. In general, the soil modulus of rupture decreased as the application rates of SMC increased. These effects can be explained by the high organic matter contents of SMC that improved soil structure mechanically (Gümüs and Şeker, 2015; Şeker, 2003), as the SMC used in the study contains significant amounts of organic substances. The modulus of rupture can also be related to the inhibitory effects of SMC on the tight unity formation of soil particles. The structural stabilization is related to organic matter inputs (Caravaca et al., 2002; Ferreras et al., 2006), and thus a significant decrease in the modulus of rupture was possibly attained with the application of SMC. Organic amendments are known to decrease bulk density and particle density in soil (Moreno et al., 2016). The absence of such effects after 62 days can be related to the decrease in aggregate stability and organic substances. This most probably resulted from the breakdown of soil aggregation and the aggregates of soil organic matter by mixing pot contents to simulate repeated cultivation (Carrizo et al., 2015; Şeker, 2003).

\subsection{Electrical conductivity (EC)}

The effects of SMC on the EC values of the soil are shown in Fig. 4. The EC values significantly increased with SMC

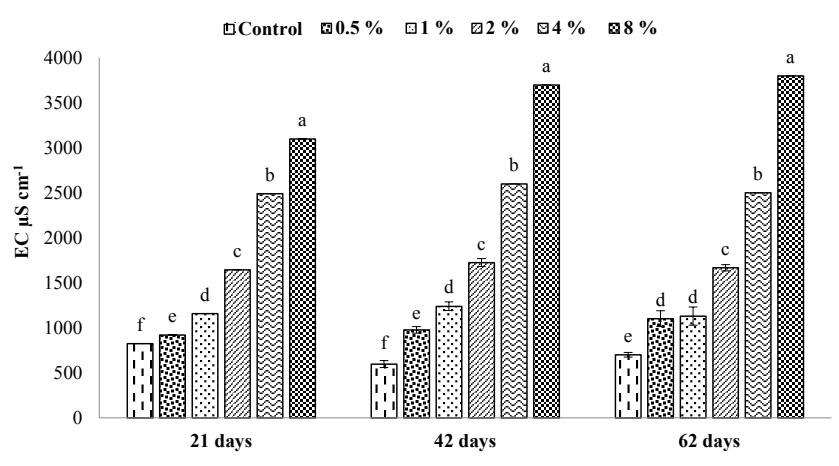

Figure 4. Effects of different rates of SMC application on soil EC (mean $\pm \mathrm{SD}<0.05$ ). Means followed by the same letter are not statistically different as determined by a least significant difference test.

and incubation periods, which may be explained by the high content of solutes in the nutrient composition of organic fragments and the remains from the materials during incubation periods (Yilmaz, 2010). EC can serve as a measure of the presence of nutrients for both cations and anions (Roy and Kashem, 2014). Soil EC indicates the mineralization of organic matter in soil and many authors have found positive correlations between EC and compounds from organic matter degradation in soil (Arthur et al., 2012; Gulser et al., 2010; Medina et al., 2012). However, in our study, EC values were still below the upper limit of $4000 \mu \mathrm{S} \mathrm{cm}$ suggested for agricultural soils, even at $8 \%$ application rates (Arthur et al., 2012; Postel and Starke, 1990; Rhoades et al., 1992).

\subsection{Soil organic carbon (SOC)}

The effects of SMC on the SOC values of the soil are shown in Fig. 5. SOC significantly increased with elevated SMC rates of application. Our results revealed SOC increments in response to the increase in SMC doses, and the strongest effects were obtained with doses of 4 and $8 \%$. In general, SOC content values increase with larger amendment rates of organic materials. SOC is known to play important roles in the maintenance and improvement of many soil proper- 


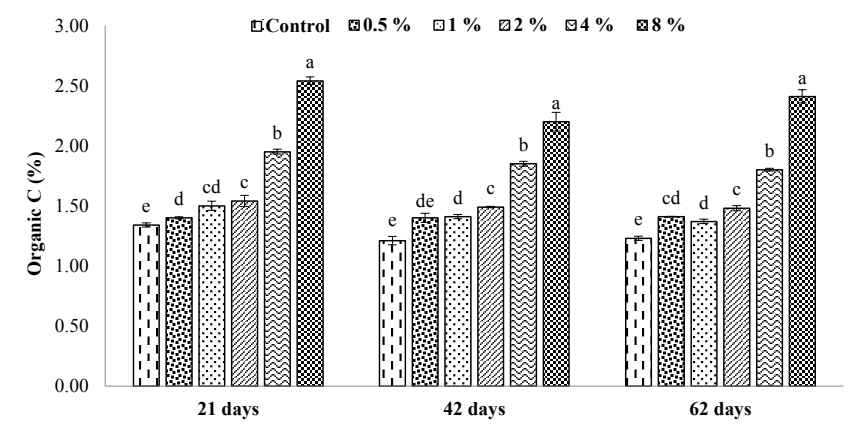

Figure 5. Effects of different rates of SMC application on soil organic carbon (mean $\pm \mathrm{SD}<0.05$ ). Means followed by the same letter are not statistically different as determined by a least significant difference test.

ties, and thus its concentration is often cited as one of the major indicators for sustaining soil productivity. Increases in soil organic carbon contents can be achieved by adding spent mushroom compost (Courtney and Mullen, 2008; Medina et al., 2012). The continuous decomposition of organic matter in the cultivated soils of arid and semiarid regions may lead to soil degradation with a consequent inability to ensure sustainable production (Aggelides and Londra, 2000). Organic amendments used in soil reclamation emanate from a variety of sources, including agriculture, forestry, and urban areas. Of those generated by agriculture, livestock manure from various species is the most prevalent (Larney and Angers, 2012). Other amendments derived from agriculture include crop residues and SMC. The rate of decomposition of organic amendments and SOC remains in the long term varies with the intrinsic quality of the amendment (Lashermes et al., 2009; Novara et al., 2015). Soil organic matter content is one of the most important soil quality indicators of soil recovery (Mahmoud and Abd El-Kader, 2015; Parras-Alcántara et al., 2015; Pulido Moncada et al., 2015) and is a good sign for soil quality (Gelaw et al., 2015). The quality of soil organic matter, soil structure, microbial activity, and rainfall intensity are, in fact, important parameters that should be evaluated and correlated to assess the fate of carbon during transportation (Novara et al., 2016). Similar results were reported by other studies (Arthur et al., 2011; Curtin and Mullen, 2007; Yazdanpanah et al., 2016).

\subsection{Total nitrogen $(\mathrm{N})$}

The effects of SMC on the total nitrogen values of the soil are shown in Fig. 6. The nitrogen content of the soil was closely dependent on the amendment rates of the SMC and, in general, the total nitrogen content of soil increased with increasing rates of SMC. The strongest effect was obtained with doses of 4 and $8 \%$. The degradation of soil and the associated losses of nitrogen can cause environmental problems and a reduction in soil fertility (García-Díaz et al., 2016,

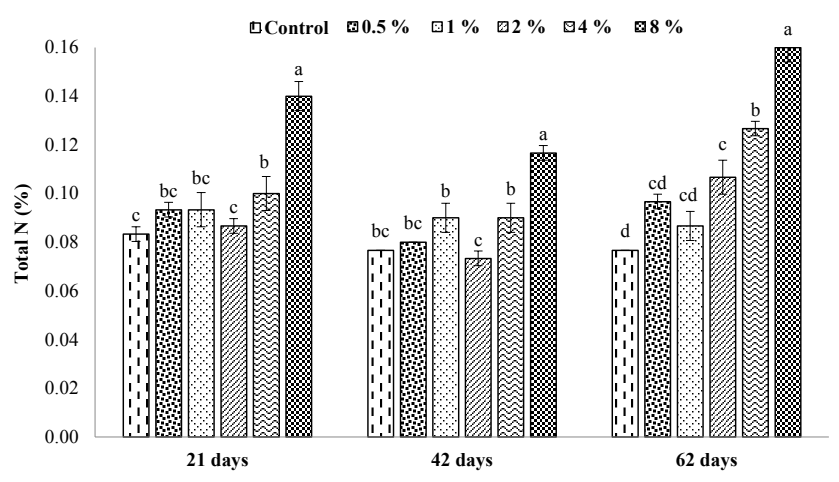

Figure 6. Effects of different rates of SMC application on total nitrogen (mean $\pm \mathrm{SD}<0.05$ ). Means followed by the same letter are not statistically different as determined by a least significant difference test.

2017). With regards to the nitrogen dynamics in the soil, the addition of the SMC produced a general increase in the organic $\mathrm{N}$ concentration throughout the experiment, especially in comparison to the control soil (Medina et al., 2012). It has been reported that the physical, chemical, and biological properties of SMC (especially the $\mathrm{C} / \mathrm{N}$ mineralization level and decomposition) may play roles in the mineralization of nitrogen from organic materials during incubation periods.

\section{Conclusions}

This study shows that the application of SMC can improve the structure of soils. In this study, the physical and chemical properties of the soil, such as aggregate stability, soil modulus of rupture, organic carbon, and total nitrogen, were improved by spent mushroom compost amendment. The addition of spent mushroom compost increased soil EC. Soil aggregate stability and the modulus of rupture were the most significantly affected parameters by SMC application. Moreover, the use of spent mushroom compost contributed to enhancing the level of organic carbon and nitrogen in the soil. In summary, the results of this study showed that SMC application is an effective way to improve soil physicochemical properties. This structural improvement can have direct benefits for farmers, land managers, and mushroom growers who require a safe disposal method for waste products.

Data availability. The data are not publicly available due to copyright issues.

Competing interests. The authors declare that they have no conflict of interest. 
Acknowledgements. The authors would like to thank Ali Sabır from the Department of Horticulture, Faculty of Agriculture, University of Selçuk for her helpful comments and Hamza Negiş from the Department of Soil Science and Plant Nutrition, Faculty of Agriculture, University of Selçuk for the helpful laboratory analysis. They would also like to thank the editors and referees for their interest and contributions.

Edited by: Miriam Muñoz-Rojas

Reviewed by: Gökhan Çayci and seven anonymous referees

\section{References}

Aggelides, S. M. and Londra, P. A.: Effects of compost produced from town wastes and sewage sludge on the physical properties of a loamy and a clay soil, Bioresource Technol., 71, 253-259, 2000.

Aksakal, E. L., Sari, S., and Angin, I.: Effects of vermicompost application on soil aggregation and certain physical properties, Land Degrad. Dev., 27, 983-986, 2015.

Annabi, M., Le Bissonnais, Y., Le Villio-Poitrenaud, M., and Houot, S.: Improvement of soil aggregate stability by repeated applications of organic amendments to a cultivated silty loam soil, Agr. Ecosyst. Environ., 144, 382-389, 2011.

Arthur, E., Cornelis, W., Vermang, J., and De Rocker, E.: Amending a loamy sand with three compost types: impact on soil quality, Soil Use Manage., 27, 116-123, 2011.

Arthur, E., Cornelis, W., and Razzaghi, F.: Compost Amendment to sandy soil affects soil properties and greenhouse tomato productivity, Compost Sci. Util., 20, 215-221, 2012.

Bal, L., Şeker, C., and Ersoy Gümüş, İ.: Kaymak TabakasıOluşumuna Fiziko-Kimyasal Faktörlerin Etkileri, Selçuk tarim ve gida bi 'li 'mleri' dergi'si', 25, 96-103, 2012.

Bone, J., Barraclough, D., Eggleton, P., Head, M., Jones, D., and Voulvoulis, N.: Prioritising soil quality assessment through the screening of sites: the use of publicly collected data, Land Degrad. Dev., 25, 251-266, 2014.

Bronick, C. J. and Lal, R.: Soil structure and management: a review, Geoderma, 124, 3-22, 2005.

Calleja-Cervantesa, M. E., Fernández-Gonzálezb, A. J., Irigoyenc, I., Fernández-Lópezb, M., Aparicio-Tejod, P. M., and Menéndeze, S.: Thirteen years of continued application of composted organic wastes in a vineyard modify soil quality characteristics, Soil Biol. Biochem., 90, 241-254, https://doi.org/10.1016/j.soilbio.2015.07.002, 2015.

Candemir, F. and Gülser, C.: Effects of different agricultural wastes on some soil quality indexes in clay and loamy sand fields, Commun. Soil Sci. Plan., 42, 13-28, 2010.

Caravaca, F., Masciandaro, G., and Ceccanti, B.: Land use in relation to soil chemical and biochemical properties in a semiarid Mediterranean environment, Soil Till. Res., 68, 23-30, 2002.

Carrizo, M. E., Alesso, C. A., Cosentino, D., and Imhoff, S.: Aggregation agents and structural stability in soils with different texture and organic carbon contents, Sci. Agr., 72, 75-82, 2015.

Cassel, D. and Nielsen, D.: Field capacity and available water capacity, Methods of Soil Analysis: Part 1 - Physical and Mineralogical Methods, 901-926, 1986.
Celik,I., Ortas, I., and Kilic, S.: Effects of compost, mycorrhiza, manure and fertilizer on some physical properties of a Chromoxerert soil, Soil Till. Res., 78, 59-67, 2004.

Cerdà, A.: Soil aggregate stability under different Mediterranean vegetation types, Catena, 32, 73-86, 1998.

Chan, K., Heenan, D., and So, H.: Sequestration of carbon and changes in soil quality under conservation tillage on lighttextured soils in Australia: a review, Anim. Prod. Sci., 43, 325334, 2003.

Courtney, R. and Mullen, G.: Soil quality and barley growth as influenced by the land application of two compost types, Bioresource Technol., 99, 2913-2918, 2008.

Curtin, J. and Mullen, G.: Physical properties of some intensively cultivated soils of Ireland amended with spent mushroom compost, Land Degrad. Dev., 18, 355-368, 2007.

Dai, Q., Liu, Z., Shao, H., and Yang, Z.: Karst bare slope soil erosion and soil quality: a simulation case study, Solid Earth, 6, 985995, https://doi.org/10.5194/se-6-985-2015, 2015.

Diaz, E., Roldfin, A., Lax, A., and Albaladejo, J.: Formation of stable aggregates in degraded soil by amendment with urban refuse and peat, Geoderma, 63, 277-288, 1994.

Doran, J., Safley, M., Pankhurst, C., Doube, B., and Gupta, V.: Defining and assessing soil health and sustainable productivity, Biological indicators of soil health, 1-28, 1997.

Erler, F. and Polat, E.: Mushroom cultivation in Turkey as related to pest and pathogen management, Isr. J. Plant Sci., 56, 303-308, 2008.

Ferreras, L., Gómez, E., Toresani, S., Firpo, I., and Rotondo, R.: Effect of organic amendments on some physical, chemical and biological properties in a horticultural soil, Bioresource Technol., 97, 635-640, 2006.

García-Díaz, A., Allas, R. B., Gristina, L., Cerdà, A., Pereira, P., and Novara, A.: Carbon input threshold for soil carbon budget optimization in eroding vineyards, Geoderma, 271, 144-149, 2016.

García-Díaz, A., Bienes, R., Sastre, B., Novara, A., Gristina, L., and Cerdà, A.: Nitrogen losses in vineyards under different types of soil groundcover. A field runoff simulator approach in central Spain, Agr. Ecosyst. Environ., 236, 256-267, 2017.

Gee, G. W., Bauder, J. W., and Klute, A.: Particle-size analysis, Methods of soil analysis. Part 1, Physical and mineralogical methods, 383-411, 1986.

Gelaw, A. M., Singh, B., and Lal, R.: Organic carbon and nitrogen associated with soil aggregates and particle sizes under different land uses in Tigray, Northern Ethiopia, Land Degrad. Dev., 26, 690-700, 2015.

Grandy, A. S., Porter, G. A., and Erich, M. S.: Organic amendment and rotation crop effects on the recovery of soil organic matter and aggregation in potato cropping systems, Soil Sci. Soc. Am. J., 66, 1311-1319, 2002.

Gulser, C., Demir, Z., and Ic, S.: Changes in some soil properties at different incubation periods after tobacco waste application, J. Environ. Biol., 31, 671-674, 2010.

Gümüs, I. and Şeker, C.: Influence of humic acid applications on modulus of rupture, aggregate stability, electrical conductivity, carbon and nitrogen content of a crusting problem soil, Solid Earth, 6, 1231-1236, https://doi.org/10.5194/se-6-12312015, 2015.

Hueso-González, P., Martínez-Murillo, J. F., and Ruiz-Sinoga, J. D.: The impact of organic amendments on forest soil properties un- 
der Mediterranean climatic conditions, Land Degrad. Dev., 25, 604-612, 2014.

Jaiarree, S., Chidthaisong, A., Tangtham, N., Polprasert, C., Sarobol, E., and Tyler, S.: Carbon budget and sequestration potential in a sandy soil treated with compost, Land Degrad. Dev., 25, 120-129, 2014.

Karlen, D., Mausbach, M., Doran, J., Cline, R., Harris, R., and Schuman, G.: Soil quality: a concept, definition, and framework for evaluation (a guest editorial), Soil Sci. Soc. Am. J., 61, 4-10, 1997.

Kemper, W. and Rosenau, R.: Aggregate stability and size distribution, in: Methods of Soil analysis, Part 1, 2nd Edn., edited by: Klute, A., Agron. Monogr. No. 9, Am. Soc. Agron.: Madison, Wis, 1986.

Ko, H. G., Park, S. H., Kim, S. H., Park, H. G., and Park, W. M.: Detection and recovery of hydrolytic enzymes from spent compost of four mushroom species, Folia Microbiol., 50, 103-106, 2005.

Larney, F. J. and Angers, D. A.: The role of organic amendments in soil reclamation: a review, Can. J. Soil Sci., 92, 19-38, 2012.

Lashermes, G., Nicolardot, B., Parnaudeau, V., Thuries, L., Chaussod, R., Guillotin, M., Lineres, M., Mary, B., Metzger, L., and Morvan, T.: Indicator of potential residual carbon in soils after exogenous organic matter application, Eur. J. Soil Sci., 60, 297310, 2009.

LECO Cooperation: Truspec carbon/nitrogen determinator, Leco Cooperation 3000, Lakeview Avenue St Joseph, M149085-2396, USA, 2003.

Mahmoud, E. and Abd El-Kader, N.: Heavy metal immobilization in contaminated soils using phosphogypsum and rice straw compost, Land Degrad. Dev., 26, 819-824, 2015.

Medina, E., Paredes, C., Bustamante, M., Moral, R., and MorenoCaselles, J.: Relationships between soil physico-chemical, chemical and biological properties in a soil amended with spent mushroom substrate, Geoderma, 173, 152-161, 2012.

MGM: Meteoroloji Genel Müdürlüğü Resmi İstatistikler (İllerimize Ait İstatistiki Veriler), 2015.

Minitab: Minitab reference manual (Release 7.1), State Coll., PA16801, USA, 1991.

Moreno, M. T., Carmona, E., Santiago, A., Ordovás, J., and Delgado, A.: Olive husk compost improves the quality of intensively cultivated agricultural soils, Land Degrad. Dev., 27, 449-459, 2016.

Mukherjee, A., Zimmerman, A. R., Hamdan, R., and Cooper, W. T.: Physicochemical changes in pyrogenic organic matter (biochar) after 15 months of field aging, Solid Earth, 5, 693-704, https://doi.org/10.5194/se-5-693-2014, 2014.

Murphy, C.: Spent mushroom compost as an amendment on tillage land, MS, University of Limerick, Ireland, 2001.

Novara, A., Rühl, J., La Mantia, T., Gristina, L., La Bella, S., and Tuttolomondo, T.: Litter contribution to soil organic carbon in the processes of agriculture abandon, Solid Earth, 6, 425-432, https://doi.org/10.5194/se-6-425-2015, 2015.

Novara, A., Keesstra, S., Cerdà, A., Pereira, P., and Gristina, L.: Understanding the role of soil erosion on $\mathrm{CO}_{2}-\mathrm{C}$ loss using $13 \mathrm{C}$ isotopic signatures in abandoned Mediterranean agricultural land, Sci. Total Environ., 550, 330-336, https://doi.org/10.1016/j.scitotenv.2016.01.095, 2016.
Özdemir, N., Uzun, S., and Yakupoglu, T.: The effect of the rates of different organic fertilizers on restoring aggregate stability and productivity of eroded soils, Biol. Agric. Hortic., 25, 175-184, 2007.

Parras-Alcántara, L., Lozano-García, B., and Galán-Espejo, A.: Soil organic carbon along an altitudinal gradient in the Despeñaperros Natural Park, southern Spain, Solid Earth, 6, 125134, https://doi.org/10.5194/se-6-125-2015, 2015.

Paz-Ferreiro, J. and Fu, S.: Biological indices for soil quality evaluation: perspectives and limitations, Land Degrad. Dev., https://doi.org/10.1002/ldr.2262, 2013.

Peng, F., Quangang, Y., Xue, X., Guo, J., and Wang, T.: Effects of rodent-induced land degradation on ecosystem carbon fluxes in an alpine meadow in the Qinghai-Tibet Plateau, China, Solid Earth, 6, 303-310, https://doi.org/10.5194/se-6-303-2015, 2015.

Postel, S. and Starke, L.: Saving water for agriculture, State of the World, 39-58, 1990.

Pulido Moncada, M., Gabriels, D., Cornelis, W., and Lobo, D.: Comparing aggregate stability tests for soil physical quality indicators, Land Degrad. Dev., 26, 843-852, 2015.

Reeve, R.: Modulus of rupture, Methods of Soil Analysis. Part 1. Physical and Mineralogical Properties, Including Statistics of Measurement and Sampling, 466-471, 1965.

Rhoades, J., Sparks, D., Page, A., Helmke, P., Loeppert, R., Soltanpour, P., Tabatabai, M., Johnston, C., and Sumner, M.: Salinity: Electrical conductivity and total dissolved solids, Methods of soil analysis. Part 3-chemical methods, 417-435, 1996.

Rhoades, J. D., Kandiah, A., and Mashali, A. M.: The use of saline waters for crop production, FAO Rome, 1992.

Richards, L.: Modulus of rupture as an index of crusting of soil, Soil Sci. Soc. Am. J., 17, 321-323, 1953.

Rodrigo Comino, J., Ruiz Sinoga, J. D., Senciales Gonzàles, J. M., Guerra-Merchàn, A., Seeger, M., and Ries, J. B.: High variability of soil erosion and hydrological processes in Mediterranean hillslope vineyards (Montes de Málaga, Spain), Catena, 145, 274 284. doi.org/10.1016/j.catena.2016.06.012, 2016.

Rodrigo Comino, J., Senciales, Gonzjles, J. M., Ramos, M. C., Martínez-Casasnovas, J. A., Lasanta, T., Brevik, E. C., and Ruiz Sinoga, J. D.: Understanding soil erosion processes in Mediterranean sloping vineyards (Montes de Málaga, Spain), Geoderma, 296, 47-59, https://doi.org/10.1016/j.geoderma.2017.02.021, 2017.

Roy, S. and Kashem, M. A.: Effects of Organic Manures in Changes of Some Soil Properties at Different Incubation Periods, Open Journal of Soil Science, 4, 81-86, 2014.

Şeker, C.: Effects of selected amendments on soil properties and emergence of wheat seedlings, Canadian J. Soil sci., 83, 615621, 2003.

Şeker, C. and Karakaplan, S.: Konya ovasında toprak özellikleri ile kırılma değerleri arasındaki ilişkiler, Tr. J. Agriculture and Forestry, 29, 183-190, 1999.

Soil Survey Staff: Keys to Soil Taxonomy, 12th USDA Natural Resources Conservation Service, Washington, D.C., 2014.

Shiralipour, A., McConnell, D. B., and Smith, W. H.: Physical and chemical properties of soils as affected by municipal solid waste compost application, Biomass Bioenerg., 3, 261-266, 1992.

Thomas, G.: Soil pH and soil acidity, in: Methods of soil analysis, Part 3., Chemical methods, edited by: Sparks, D. L., Soil Science Society of America: Madison, WI, 475-490, 1996. 
Tui'k, T. İ. Ö.: Statistics on plant products 2009-2015, Turkish Statistics Institute, http://www.tuik.gov.tr, 2015.

Turgut, B. and Kose, B.: Improvements in aggregate stability of sediments supplemented with tea waste and farmyard manure, Spanish Journal of Soil Science, 6, 98-106, 2016.

Uzun, I.: Use of spent mushroom compost in sustainable fruit production, Journal of Fruit and Ornamental Plant Research, 12, 157-165, 2004.

Wu, Y., Xu, G., and Shao, H. B.: Furfural and its biochar improve the general properties of a saline soil, Solid Earth, 5, 665-671, https://doi.org/10.5194/se-5-665-2014, 2014.

Yazdanpanah, N., Mahmoodabadi, M., and Cerdà, A.: The impact of organic amendments on soil hydrology, structure and microbial respiration in semiarid lands, Geoderma, 266, 58-65, 2016.
Yilmaz, E.: Changes of some soil properties by agricultural processing waste (soybean pulp) amendment, Journal of Food, Agr. Environ., 8, 1057-1060, 2010.

Yu, Y. and Jia, Z. Q.: Changes in soil organic carbon and nitrogen capacities of Salix cheilophila Schneid along a revegetation chronosequence in semi-arid degraded sandy land of the Gonghe Basin, Tibet Plateau, Solid Earth, 5, 1045-1054, https://doi.org/10.5194/se-5-1045-2014, 2014.

Zhang, L. and Sun, X.: Changes in physical, chemical, and microbiological properties during the two-stage co-composting of green waste with spent mushroom compost and biochar, Bioresource Technol., 171, 274-284, 2014. 